\title{
Accuracy-Based Proficiency Testing of Creatinine Measurement: 7 Years' Experience in Korea
}

Tae-Dong Jeong ${ }^{1}$, Hye Ah Lee ${ }^{2}$, Kyunghoon Lee $^{3}$, and Yeo-Min Yun ${ }^{4}$ ${ }^{1}$ Department of Laboratory Medicine, Ewha Womans

University School of

Medicine; ${ }^{2}$ Clinical

Trial Center, Ewha

Womans University

Mokdong Hospital,

Seoul; ${ }^{3}$ Department of Laboratory Medicine, Seoul National University Bundang Hospital, Seongnam; ${ }^{4}$ Department of Laboratory Medicine, Konkuk University School of Medicine, Seoul, Korea

Corresponding author: Tae-Dong Jeong Department of Laboratory Medicine, Ewha Womans University School of Medicine, 25 Magokdong-ro 2-gil, Gangseogu, Seoul 07804, Korea Tel: $+82-2-6986-3386$

Fax: +82-2-6986-3389

E-mail: tdjeong@ewha.ac.kr

pISSN: $2384-2458$

elSSN: 2288-7261
Background: Standardization of creatinine assay is consistently performed and much effort has been put into improving the accuracy of the results. We aimed to analyze the results of accuracy-based proficiency testing of creatinine assays performed by the Korea Association of External Quality Assessment Service from 2011 to 2017 to assess the current state of creatinine assays in Korea.

Methods: From 2011 to 2017, the accuracy-based proficiency testing of creatinine was performed twice a year. We analyzed the results obtained from the participating laboratories and calculated the year-wise bias. The acceptable limit of bias was as follows: $\pm 11.4 \%$ for creatinine concentration $>1.0 \mathrm{mg} / \mathrm{dL}$, and $0.114 \mathrm{mg} / \mathrm{dL}$ for creatinine concentration $\leq 1.0 \mathrm{mg} /$ $\mathrm{dL}$. The trend of bias with the major instruments and reagent manufacturers were analyzed.

Results: The number of participating laboratories was 54 in 2011, which gradually increased to 146-178 after 2015. For each of the three samples used in the survey, the percentage of laboratories whose biases in the results were within the acceptable limits was $33.3 \%$ for the first time in 2011, which gradually increased to $74.7 \%-85.0 \%$ after 2014 . The mean biases in all the results of the participating laboratories were $11.1 \%$ in 2011 (1st trial) and $2.4 \%$ in 2017 (2nd trial). The biases in the results with the major instruments and reagents differed according to the manufacturers.

Conclusions: The mean bias in the results obtained from the participating laboratories in the accuracy-based proficiency testing of creatinine surveys showed a decreasing trend.

(J Lab Med Qual Assur 2019;41:13-23)

Key Words: Accuracy, Bias, Creatinine, Proficiency testing

Received November 29, 2018, Revision received December 27, 2018, Accepted January 7, 2019

\section{서론}

진단검사의학 검사결과는 의학적 의사결정에 중요한 역 할을 하므로 이상적인 진단검사의학 검사결과는 어느 병 원, 어느 검사실에서 검사하더라도 서로 비교 가능해야 한다 〔1]. 임상검사실에서 사용하는 검사방법, 검사시약 및 검사
장비 종류에 따른 결과 차이를 최소화하기 위해 검사의 표 준화(standardization) 및 일치화(harmonization)가 필요 하다[2]. 진단검사의학 검사결과의 가치를 높이기 위해 검 사의 표준화 및 일치화에 대한 노력이 지속적으로 이루어지 고 있으며, 대한임상검사정도관리협회에서는 2009년부터 표 준검사실(reference laboratory)에서 참고방법(reference 
measurement procedure)으로 측정한 참값(target value)을 기준으로 외부정도관리 결과를 평가하는 정확도기반 신빙도 조사사업을 시행하고 있다. 대한임상검사정도관리협회의 정 확도기반 신빙도조사사업은 2009년 당화혈색소(hemoglobin $\mathrm{A1c}$ )를 시작으로 2011년도부터는 크레아티닌, 총 콜레스테 롤, 중성지방, 고밀도지단백 및 저밀도지단백 검사가 추가되었 다[3].

크레아티닌 검사결과는 전반적인 신기능 평가에 사용되는 추정사구체여과율(estimated glomerular filtration rate) 계 산에 필요한 주요 변수이다[4]. 크레아티닌검사와 추정사구체 여과율은 만성신질환(chronic kidney disease) 및 급성신손 상(acute kidney injury)의 진단, 분류 및 치료방침 결정 등에 사용되므로 정확한 검사가 필수적이다 $[5,6]$. 임상검사실에서 는 크레아티닌 검사결과의 정확도를 높이기 위해 측정소급성 (metrological traceability)이 검증된 보정물질(calibrator)을 사용하고, 또한 검사의 정확도를 평가할 수 있는 외부정도관리 에 주기적으로 참여할 필요가 있다.

저자들은 대한임상검사정도관리협회에서 주관한 정확도기 반 크레아티닌 신빙도조사사업 자료(2011-2017)를 분석하여 국내 임상검사실의 크레아티닌검사 정확도 현황을 파악하고 자 하였다.

\section{재료 및 방법}

\section{1. 정확도기반 크레아티닌검사 신빙도조사 자료}

2011년부터 2017년까지 대한임상검사정도관리협회에서 시 행한 정확도기반 크레아티닌검사 신빙도조사 원시자료를 사 용하였다. 정확도기반 크레아티닌검사 신빙도조사는 연간 2 회 시행되었고, 매 회차마다 신빙도조사를 위해 자가제조 혈청 (commutable frozen serum) 3개 검체를 사용하였다.

\section{2. 크레아티닌 참값 측정}

각 검체의 크레아티닌 농도 참값은 참고검사실 국제인 증기관(ISO 17025 및 ISO 15195)인 Reference Material Institute for Clinical Chemistry Standards (ReCCS, Yokohama, Japan) 검사실에서 Joint Committee for Traceability in Laboratory Medicine에서 인증한 참고방법 (isotope-dilution mass spectrometry, IDMS)으로 측정한 값 으로 정하였다.

\section{3. 정확도기반 크레아티닌검사 신빙도조사 허용기준}

정확도기반 크레아티닌검사 신빙도조사의 허용기준은
National Kidney Disease Education Program (NKDEP)에 서 제시한 총 허용오차를 근거로 판단하였다[7]. 크레아티닌 농도가 $1 \mathrm{mg} / \mathrm{dL}$ 이하인 경우 $\mathrm{NKDEP}$ 기준을 절대값으로 변 형하여 적용하였다. 즉 크레아티닌 농도가 $1 \mathrm{mg} / \mathrm{dL}$ 을 초과할 경우 신빙도조사 허용기준을 $\pm 11.4 \%$ 로 하였고, 크레아티닌 농도가 $1 \mathrm{mg} / \mathrm{dL}$ 이하일 경우 신빙도조사 허용기준을 \pm 0.114 $\mathrm{mg} / \mathrm{dL}$ 로 하였다.

\section{4. 자료분석 및 통계}

2011년부터 2017년까지 연도별 정확도기반 크레아티닌검 사 참여기관 수와 연도별 참여기관의 주요 검사장비 및 주요 검사시약 제조사 분포를 조사하였다. 또한 신빙도조사 허용기 준을 적용하여 연도별 acceptable/unacceptable 기관 분포 추 이를 분석하였다. 각 회차마다 3 개 검체를 사용하므로 3 개 검 체 모두 허용기준을 만족하는 경우 'acceptable'로 분류하였 고, 이외에는 'unacceptable'로 분류하였다. 크레아티닌 농도 를 회신하지 않은 경우는 분석에서 제외하였다.

전체 참여기관을 대상으로 연도별 크레아티닌검사의 바이어 스 경향을 분석하였다. 각 회차별 평균 바이어스 $(\%)$ 값은 일 반선형화 모델(generalized linear model)로 평균 및 평균의 95\% 신뢰구간을 구하였다. 연도별(회차별) 바이어스 경향성 을 파악하기 위해 선형회귀분석을 시행하였다. 정확도기반 크 레아티닌검사 신빙도조사를 처음 시작한 2011년 1회차 값을 기준으로 크레아티닌검사의 바이어스 $(\%)$ 가 통계적으로 의미 있게 감소했는지 여부를 파악하기 위해 Dunnett 방법을 통해 사후검정(post-hoc)을 수행하였다. 2011년부터 2017년까지 총 14 회의 신빙도조사 중 참여 횟수 분포를 고려하여 75 백분 위수에 해당하는 10 회 이상 참여한 경우를 연속참여기관으로 정의하여, 10 회차 이상 연속적으로 참여한 기관의 연도별 바 이어스 $(\%)$ 경향을 추가로 분석하였다.

메타분석(meta-analysis)을 사용하여 연도별 주요 검사장 비 제조사 및 검사시약 제조사별 바이어스 $(\%)$ 경향을 분석하 였다. 주요 검사장비 및 검사시약 제조사는 10 개 이상 기관에 서 사용 중인 제조사를 기준으로 하였다. 주요 검사장비 및 검 사시약 제조사 이외의 경우는 기타(others)로 분류하였다. 검 사장비 및 검사시약 정보가 없는 경우는 분석에서 제외하였다. 메타회귀분석(meta-regression)을 통해 검사장비 및 검사시 약 제조사 간 차이가 있는지를 평가하였으며, 검사장비와 시약 모두 subtotal \%bias 값이 낮은 제조사를 기준으로 비교하였 다.

통계분석을 위해 SAS ver. 9.4 (SAS Institute Inc., Cary, NC, USA), STATA SE ver. 10.0 (Stata Corp., College 


\section{Journal of LABORATORY MEDICINE and QUALITY ASSURANCE}

Tae-Dong Jeong et al • Accuracy-Based PT for Creatinine

Table 1. Accuracy-based proficiency testing of creatinine assay conducted by the Korean Association of External Quality Assessment Service from 2011 to 2017

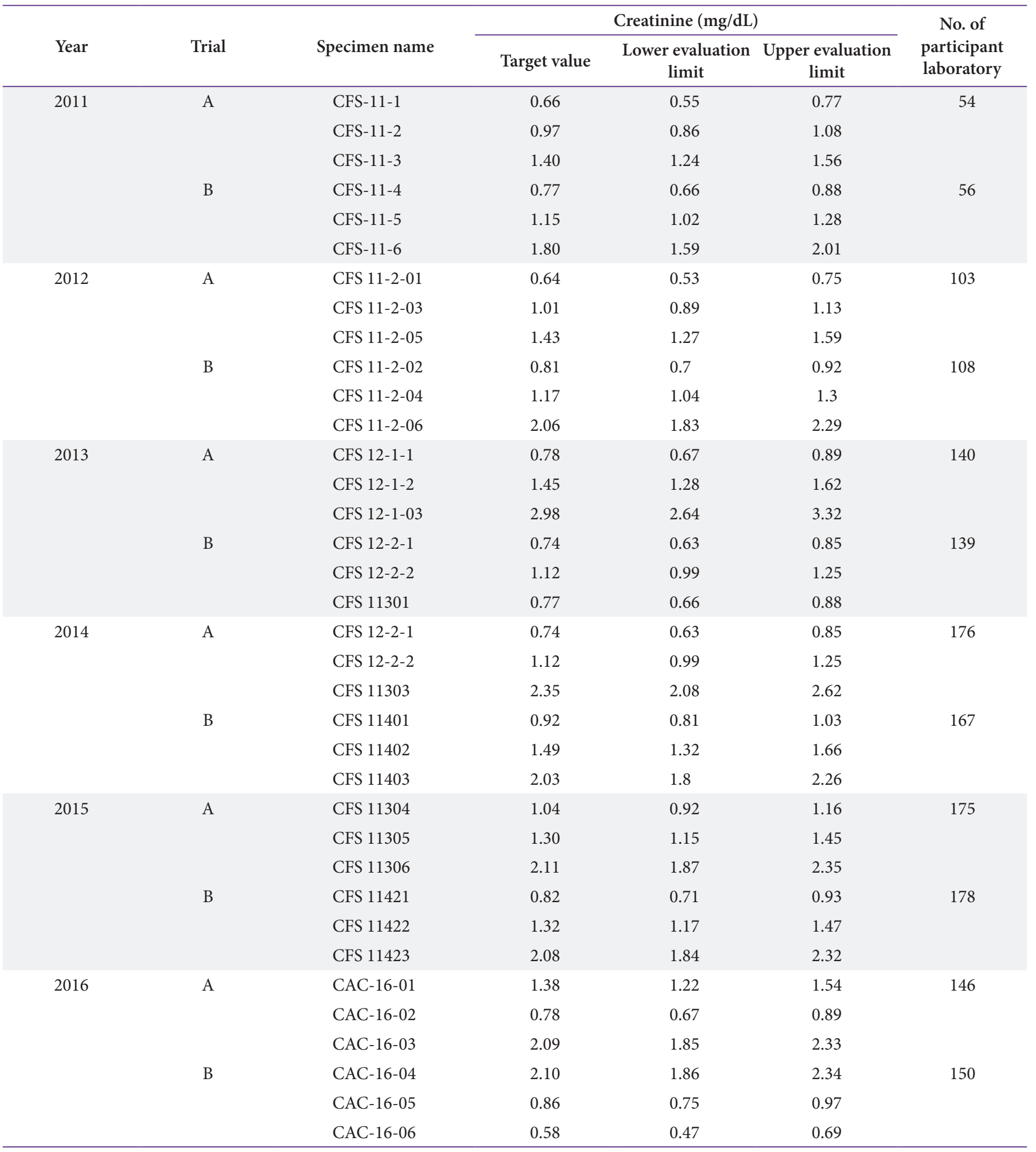

(Continued to the next page) 


\section{Journal of LABORATORY MEDICINE and QUALITY ASSURANCE}

Tae-Dong Jeong et al • Accuracy-Based PT for Creatinine

Table 1. Continued

\begin{tabular}{|c|c|c|c|c|c|c|}
\hline \multirow[b]{2}{*}{ Year } & \multirow[b]{2}{*}{ Trial } & \multirow[b]{2}{*}{ Specimen name } & \multicolumn{3}{|c|}{ Creatinine $(\mathrm{mg} / \mathrm{dL})$} & \multirow{2}{*}{$\begin{array}{c}\text { No. of } \\
\text { participant } \\
\text { laboratory }\end{array}$} \\
\hline & & & Target value & $\begin{array}{c}\text { Lower evaluation } \\
\text { limit }\end{array}$ & $\begin{array}{c}\text { Upper evaluation } \\
\text { limit }\end{array}$ & \\
\hline \multirow[t]{6}{*}{2017} & A & CAC-17-01 & 0.56 & 0.45 & 0.67 & 153 \\
\hline & & CAC-17-02 & 0.82 & 0.71 & 0.93 & \\
\hline & & CAC-17-03 & 2.14 & 1.9 & 2.38 & \\
\hline & $\mathrm{B}$ & CAC-17-04 & 1.01 & 0.89 & 1.13 & 167 \\
\hline & & CAC-17-05 & 0.68 & 0.57 & 0.79 & \\
\hline & & CAC-17-06 & 0.70 & 0.59 & 0.81 & \\
\hline
\end{tabular}

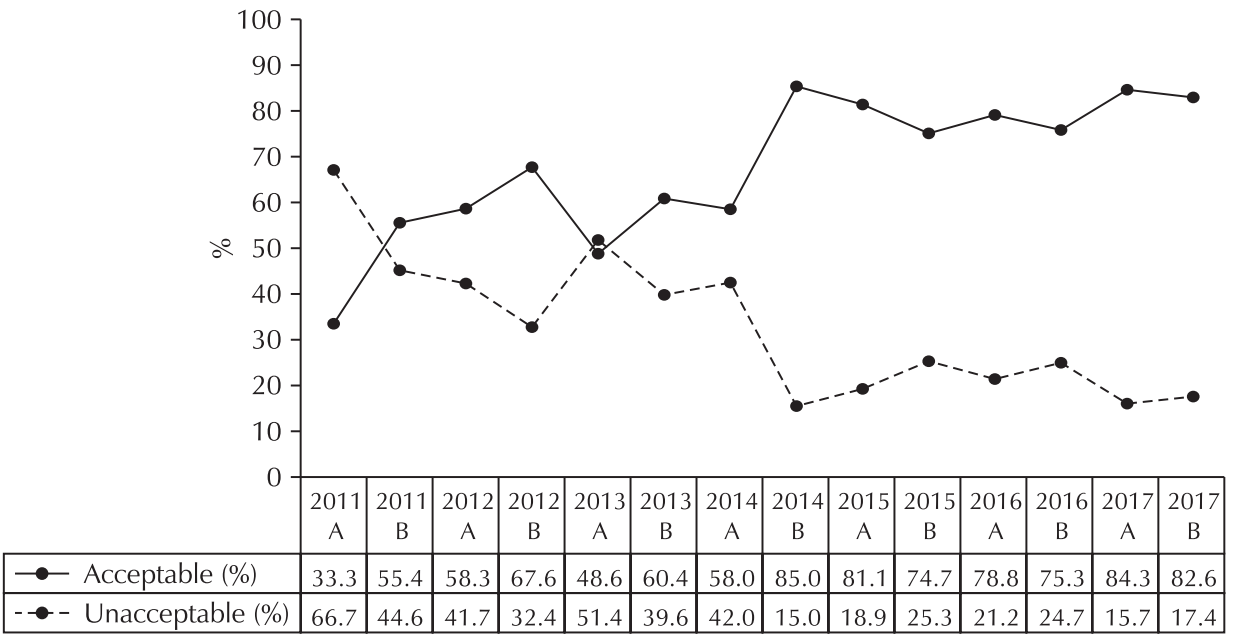

Fig. 1. Proportion of acceptable laboratories in the accuracy-based proficiency testing of creatinine assay conducted by the Korean Association of External Quality Assessment Service from 2011 to 2017.

A

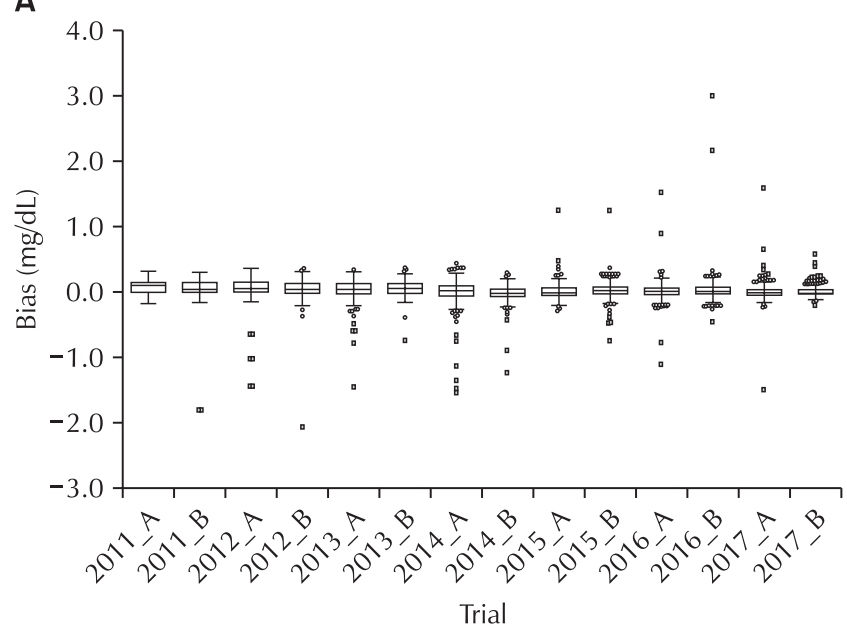

B

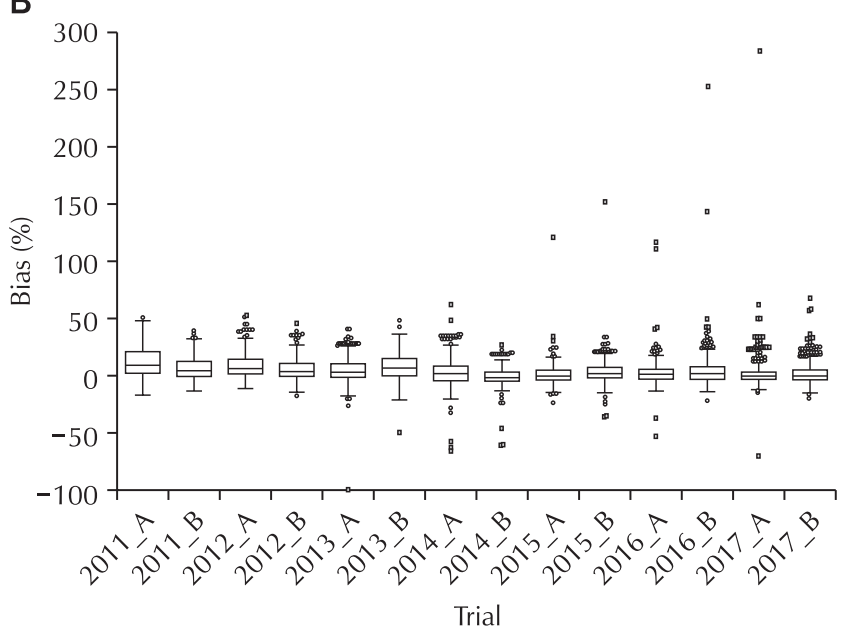

Fig. 2. Box-and-whisker plot showing the bias and percent bias in the accuracy-based proficiency testing of creatinine assay conducted by the Korean Association of External Quality Assessment Service from 2011 to 2017. In the box-and-whisker plot, the central boxes represent the values from the 25th and 75th percentile, the middle lines represents the medians, the small empty circles represents outlier values (smaller than the first quartile minus 1.5 times the interquartile range, or larger than the third quartile plus 1.5 times the interquartile range), and the small gray squares represent far outlier values (smaller than the first quartile minus 3 times the interquartile range, or larger than the third quartile plus 3 times the interquartile range). 


\section{Journal of LABORATORY MEDICINE and QUALITY ASSURANCE}

Tae-Dong Jeong et al $\bullet$ Accuracy-Based PT for Creatinine

Station, TX, USA) 및 MedCalc Statistical Software ver. 18.10.2 (MedCalc Software bvba, Ostend, Belgium) 프로 그램을 사용하였다.

\section{결과}

정확도기반 크레아티닌검사 신빙도조사 참여기관 수는 2011 년도 1 회차 54 개 기관, 2 회차 56 개 기관이었으며, 2012 년도부터 100 개 이상의 기관이 참여하여 2015년도까지 참여 기관 수가 점차 증가하였고(2015년 1 회차 175 개 기관, 2 회차 178 개 기관), 2016년도와 2017년도는 2015년도와 비교하여 소폭 감소하였다(Table 1). 각 회차에서 사용된 검체의 크레아 티닌 농도 참값과 허용기준을 적용한 상한 및 하한 크레아티닌 농도는 Table 1에 요약하였다.

2017년 2회차 신빙도조사 자료를 기준으로 참여기관에 서 사용한 검사장비 제조사는 Roche (45기관), Beckman Coulter (43기관), Hitachi Corporation (34기관), Siemens (22기관), Toshiba (20기관) 순이었고, 검사시약 제조사는 Roche (57기관), Beckman Coulter (40기관), Sekisui (26기 관), Siemens (20기관) 순이었다. 연도별 검사장비 및 검사시 약 제조사 분포는 Supplemental Figs. 1, 2에 요약하였다.

정확도기반 크레아티닌검사 신빙도조사사업 판정결과 각 회차당 배포된 3 개 검체가 모두 허용기준을 만족하는 참여기 관은 2011 년 1 회차가 18 개 기관(33.3\%), 2회차 31 개 기관 (55.4\%)이었다. 2011년 이후 허용기준을 만족하는 기관 비율 이 점차 증가하여 2014년 2회차는 $85.0 \%$ (142개 기관)으로 신빙도조사가 시행된 7년 동안 가장 높았다(Fig. 1).

회차별 바이어스 분포는 Fig. 2에 요약하였다. 바이어스 $(\mathrm{mg} / \mathrm{dL})$ 는 2012년 2차 CFS 11-2-06 물질의 negative 바이어 스가 $-2.06 \mathrm{mg} / \mathrm{dL}$ 로 가장 컸고, 2016년 2차 CAC-16-04 물 질의 positive 바이어스가 $3.01 \mathrm{mg} / \mathrm{dL}$ 로 가장 컸다.

전체 참여기관에서 각 회차별 평균 바이어스(\%)는 2011년 도 1 회차가 $11.1 \%$ 였고, 이후 점차 감소하는 경향을 보였다 (P for trend <0.001) (Fig. 3). 전체 참여기관에서 신빙도조 사 회차가 진행될수록 평균 바이어스가 약 $0.50 \%$ 씩 (standard error $[\mathrm{SE}]=0.04, P$-value $<0.0001)$ 감소하였다. Dunnett 방법을 통한 사후검정결과 2012년도 1회차(2012_A)를 제외 하고 2011년 1회차의 평균 바이어스(11.1\%)와 비교하여 모두 의미 있게 감소하였다(Fig. 3). 2017년은 1회차와 2회차 모두 $2.4 \%$ 의 평균 바이어스를 보였다.

2011-2017년 동안 10회 이상 정확도기반 크레아티닌 신빙 도조사에 참여한 기관은 총 96 개 기관이었다. 연속 참여기관
의 평균 바이어스는 2011 년도 1 회차가 $10.1 \%$ 였고, 전체 참 여기관과 유사하게 평균 바이어스(\%)가 지속적으로 감소하 는 경향을 보였다 (P for trend <0.001) (Fig. 3). 연속 참여 기관의 경우 회차가 진행될수록 평균 바이어스가 약 $0.58 \%$ 씩 $(\mathrm{SE}=0.04, P$-value <0.0001) 감소하였다. Dunnett 방법을 통한 사후검정에서 2011년 1회차의 평균 바이어스는 $10.1 \%$ 로 이후 각 회차 평균 바이어스 값은 2012년도 1회차(2012 $\mathrm{B}$ )를 제외하고 모두 의미 있게 감소하여 2017년은 1회차 $0.7 \%, 2$ 회차 $1.4 \%$ 의 평균 바이어스를 보였다.

연도별 주요 검사장비 제조사별 바이어스 분석결과는 Fig. 4에 요약하였다. 메타분석을 통한 평가에서 이질성 정도가 높 아 무작위효과모형(random effect model)으로 전체(total) 값 을 산출하였다. 메타회귀분석을 통해 검사장비 제조사 간 차 이가 있는지를 평가하였으며, subtotal \%bias 값이 낮은 검사 장비 제조사(Roche)를 기준으로 분석하였다. Roche 회사장비 기준으로 Beckman Coulter 회사장비는 통계적으로 유의한 차이를 보이지 않았으나 $(P=0.56)$, Siemens 회사장비는 경 계성 유의수준 정보를 보였고 $(P=0.06)$, Hitachi $(P<0.001)$, Toshiba $(P<0.001)$, others $(P=0.006)$ 는 의미 있게 차이가 있었다.

연도별 주요 검사시약 제조사별 바이어스 분석결과는 Fig. 5

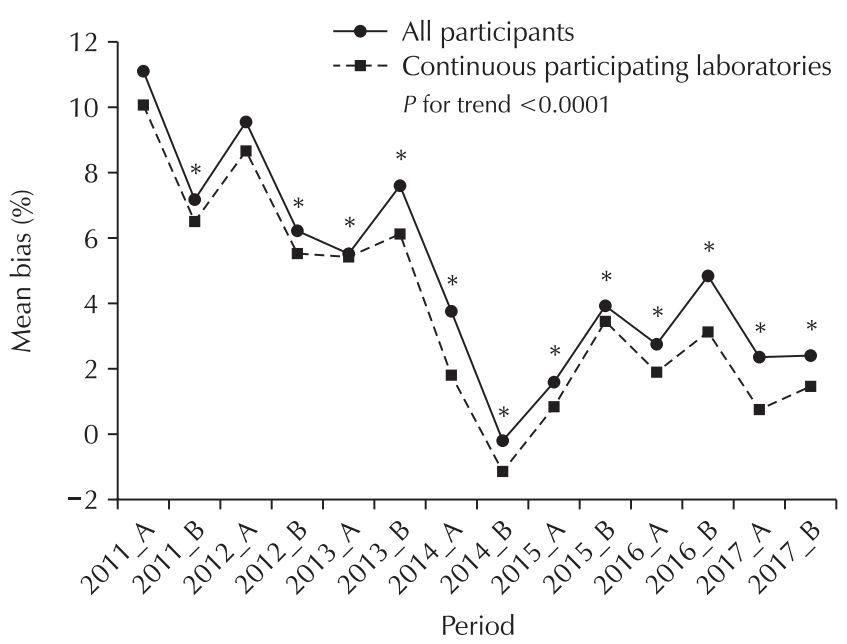

Fig. 3. Comparison of the mean percentage bias in the results of the participating laboratories involved in the accuracybased proficiency testing of creatinine assay conducted by the Korean Association of External Quality Assessment Service from 2011 to 2017 . The solid line represents all the participating laboratories at each trial. The dotted line represents the laboratories that participated in $>10$ trials from 2011 to 2017 (n=96). ${ }^{\star}$ Dunnett adjusted $P$-value (control: 2011_A) $<0.05$. 


\section{Journal of LABORATORY MEDICINE and QUALITY ASSURANCE}

Tae-Dong Jeong et al $\bullet$ Accuracy-Based PT for Creatinine

에 요약하였다. Others 분류 중 HanLab, Diasys, Wako는 추 가로 분석하였다(Supplemental Fig. 3). 메타분석을 통한 평 가에서 이질성 정도가 높아 무작위효과모형으로 전체 값을 산 출하였다. 메타회귀분석을 통해 검사시약 제조사 간 차이가 있 는지를 평가하였으며, subtotal \%bias 값이 낮은 검사시약 제 조사(Roche)를 기준으로 분석하였다. Roche 회사시약 기준으 로 Beckman Coulter $(P=0.254)$, Siemens $(P=0.070)$ 회사 시약은 통계적으로 유의한 차이를 보이지 않았으나, Sekisui
$(P<0.001)$, others $(P<0.001)$ 는 의미 있게 차이가 있었다.

\section{고찰}

임상검사실에서는 정확도기반 신빙도조사 참여를 통해 일상 적인 검사방법(routine method)의 정확도를 비교적 쉽게 확 인할 수 있다. 대한임상검사정도관리협회의 정확도기반 크레 아티닌검사 신빙도조사사업에 참여한 기관은 일반화학(크레
Instrument

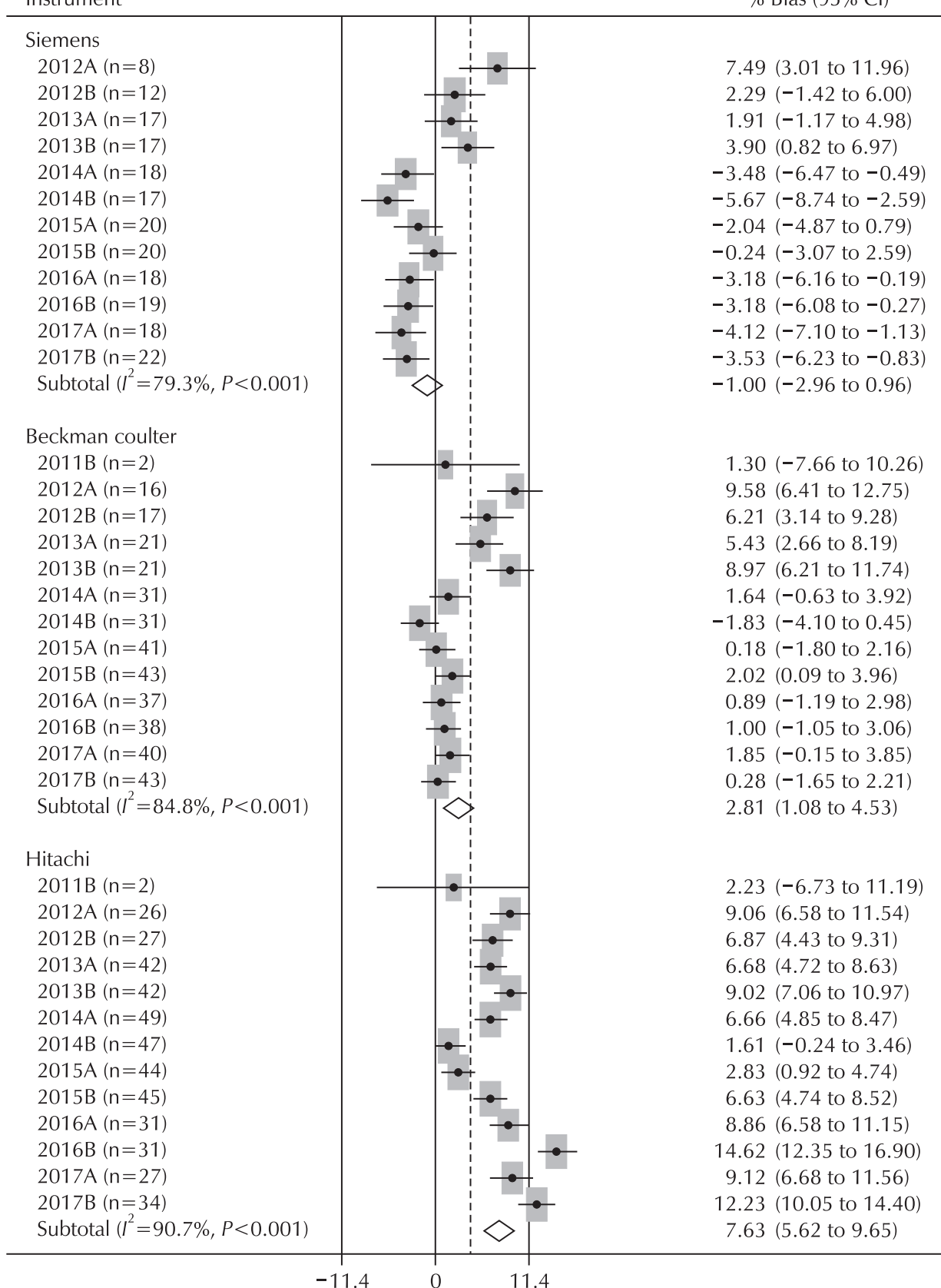

Fig. 4. Forest plot showing the accuracy-based proficiency testing of creatinine assay as per instrument manufacturers. Abbreviation: $\mathrm{CI}$, confidence interval (continued to the next page). 


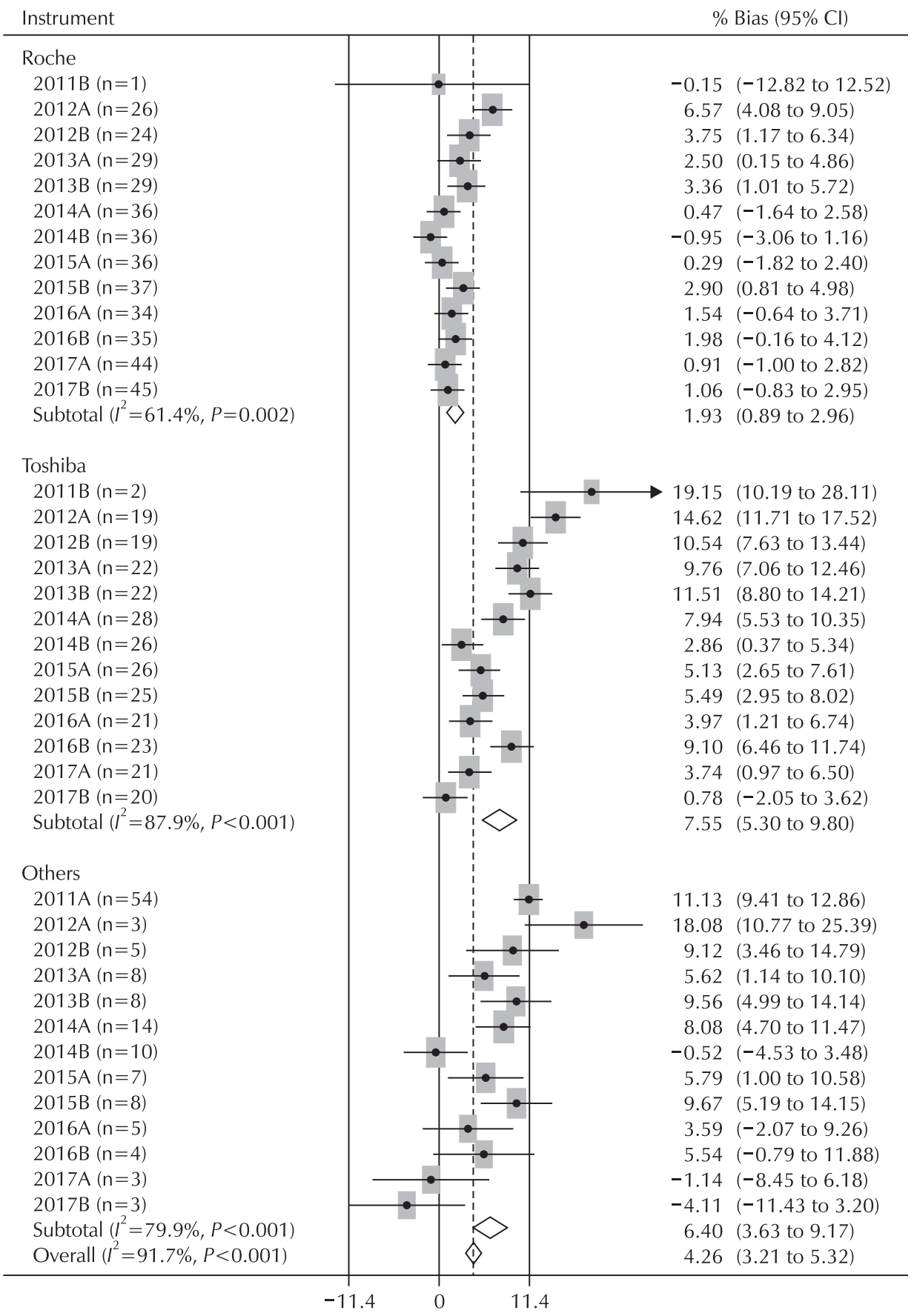

Fig. 4. Continued.
아티닌) 외부정도관리에 참여하는 기관(2016년 4회차 1,201 기관, 2017 년 4회차 1,504 기관) 대비 약 $11 \%-12 \%$ 가량이었 다. 정확도기반 신빙도조사는 참여집단(peer group)의 평균 으로 외부정도관리 결과를 해석하는 방식과 달리 표준검사 법에 의해 측정한 참값으로 결과를 평가하므로 검사의 정확 도를 직접 확인할 수 있는 장점이 있다. 검사방법에 계통오차 (systematic error)가 있다면 참여 집단의 평균으로 외부정도
관리를 해석하는 방법으로는 검사의 정확도를 파악하는데 제 한점이 있다. 따라서 일반화학(크레아티닌) 외부정도관리 프 로그램에 참여하더라도 크레아티닌검사의 전반적인 질 향상 을 위해 정확도기반 신빙도조사사업에 적극적으로 참여하는 것이 권장된다.

정확도기반 크레아티닌 신빙도조사사업이 시작된 2011년 1 회차에는 많은 검사실에서 크레아티닌 측정값을 실제보다 높 


\section{Journal of LABORATORY MEDICINE and QUALITY ASSURANCE}

Tae-Dong Jeong et al $\bullet$ Accuracy-Based PT for Creatinine

게 보고하였다. 이는 곧 추정사구체여과율 값을 과소 추정했 다는 것을 의미한다. 신빙도조사사업이 진행되면서 바이어스 가 점차 개선되어 2014년 이후에는 평균 바이어스가 2\%-4\% 가량으로 $\mathrm{NKDEP}$ 에서 제시한 크레아티닌검사의 최소 바이어 스 목표(minimum bias goal)인 $5.1 \%$ 이내였다[7]. 비록 정확 도기반 크레아티닌 신빙도조사사업이 진행될수록 참여기관의
평균 바이어스(\%)가 지속적으로 감소하고 있었지만, 각 회차 당 배포된 세 가지 정도관리물질이 모두 $\mathrm{NKDEP}$ 에서 제시한 크레아티닌검사의 최적 바이어스 목표(optimum bias goal)인 $1.7 \%$ 를 만족하는 참여기관 수는 2016년 2회차의 150 개 참여 기관 중 한 기관도 없었고, 2017년 2회차에도 167 개 기관 중 6 개 기관에 불과하였다. 따라서 국내 임상검사실의 크레아티닌

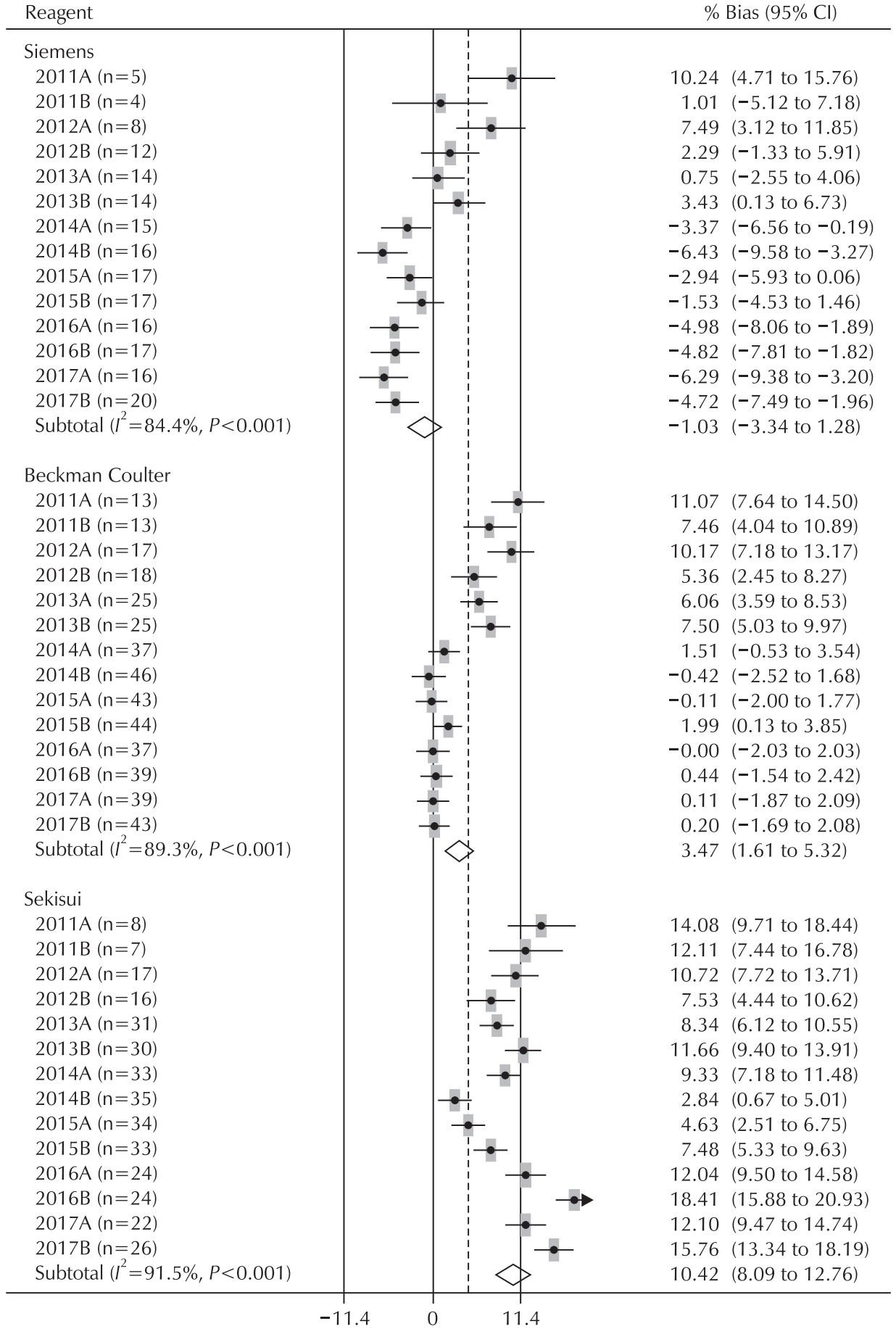

Fig. 5. Forest plot showing the accuracy-based proficiency testing of creatinine assay as per reagent manufacturers. Abbreviation: CI, confidence interval (continued to the next page). 


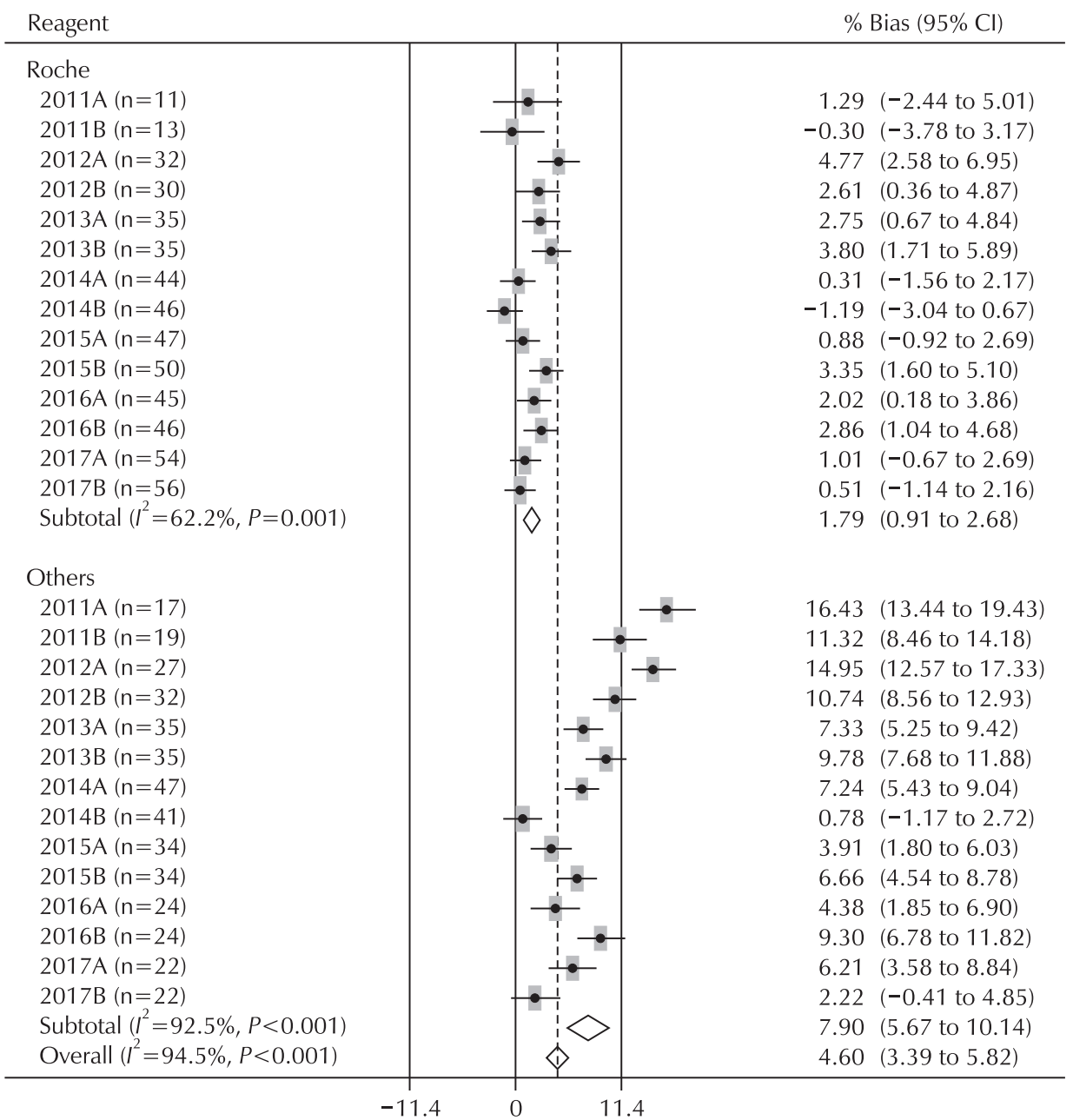

검사 정확도 향상을 위해 지속적인 노력이 필요하다고 생각된 다.

Killeen 등[8]은 미국 College of American Pathologists (CAP)의 외부정도관리에 참여하는 기관을 대상으로 2003년 과 2011년의 크레아티닌검사 정확도 현황에 대해 보고한 바 있다. 2003년에는 크레아티닌검사의 표준화가 이루어지지 않 은 시점으로 C-02(참값: $0.902 \mathrm{mg} / \mathrm{dL} ; 2003$ survey) 물질의 바이어스 분포는 $0.00 \mathrm{mg} / \mathrm{dL}$ 에서 $0.20 \mathrm{mg} / \mathrm{dL}$ 였다. 반면, 크 레아티닌검사의 표준화에 대한 노력으로 대부분의 참여기관이 IDMS-traceable calibrator를 사용했던 2011년에는 LN2401 물질(target value: $0.77 \mathrm{mg} / \mathrm{dL}$; CAP LN24 2011A)의 바 이어스 분포가 검사장비 종류에 따라 $-0.03 \mathrm{mg} / \mathrm{dL}$ 에서 0.06 $\mathrm{mg} / \mathrm{dL}$ 로 감소하였다[8]. 저자들의 연구에서도 2011년부터 2017년까지 시행된 대한임상검사정도관리협회의 정확도기반 크레아티닌 신빙도조사사업 결과가 이와 유사한 경향이었다. 하지만 CAP LN24-01 검체의 참값과 비슷한 2017년 2회차
CAC-17-06 물질(target value: $0.70 \mathrm{mg} / \mathrm{dL}$ )의 경우 바이어 스 분포가 $-0.11 \mathrm{mg} / \mathrm{dL}$ 에서 $0.40 \mathrm{mg} / \mathrm{dL}$ 로, 국내 임사검사 실의 크레아티닌검사 바이어스가 $\mathrm{CAP}$ 외부정도관리에 참여 하는 기관보다 상대적으로 컸다.

2011년부터 2013년까지 참여기관의 평균 바이어스 분포는 5.5\%-11.1\%인 반면, 2014년부터 2017년까지는 평균 바이어 스가 $-0.2 \%-4.9 \%$ 였다. 2014 년 이후 크레아티닌검사의 바이 어스가 감소한 주요한 요인으로 크레아티닌검사 표준화와 관 련한 IDMS-traceable calibrator 사용을 들 수 있다. 크레아티 닌검사에 표준화된 calibrator를 사용하면서 크레아니틴 측정 값이 약 0.1-0.2 mg/dL 감소하였고 $[9,10]$, 이는 크레아티닌검 사의 바이어스를 자연적으로 감소시키는 역할을 했을 가능성 이 있다. 이러한 현상은 검사장비 및 검사시약 제조사별 메타 분석결과에서 calibrator 영향으로 추정되는 바이어스 감소 경 향에서도 관찰할 수 있었다. 신빙도조사사업에 참여하는 기간 동안 바이어스가 감소되는 또 다른 요인으로는 각 검사실에서 
외부정도관리를 수행하는 과정에서 지속적으로 크레아티닌검 사의 질 향상에 관심을 가졌기 때문일 수 있다[11]. 10회 이상 연속적으로 신빙도조사사업에 참여한 기관의 평균 바이어스 가 전체 참여기관보다 소폭 낮은 것이 검사의 정확도에 대한 지속적인 관심이 궁극적으로 검사의 질 향상을 가져올 수 있다 는 것을 반증한다.

저자들은 연도별 주요 검사장비 제조사 및 검사시약 제조사 별 크레아티닌검사의 바이어스 경향을 분석하였다. 가장 최 근인 2017년 2회차 신빙도조사 결과 기준으로, 크레아티닌검 사 평균 바이어스의 $95 \%$ 신뢰구간이 $\pm 11.4 \%$ 이내인 검사장 비 제조사는 Siemens, Beckman Coulter, Roche, Toshiba 등이었고, 검사시약 제조사는 Siemens, Beckman Coulter, Roche 등이었다. 검사장비 제조사 Hitachi와 검사시약 제조사 Sekisui의 경우 크레아티닌검사의 평균 바이어스의 $95 \%$ 신 뢰구간 상한이 $+11.4 \%$ 를 상회하였다. 검사시약 제조사의 경 우 Siemens는 Roche와 Beckman Coulter와는 달리 소폭의 negative 바이어스를 보이는 경향이 있었지만 통계적으로 유 의한 차이는 아니었다.

본 연구에는 몇 가지 제한점이 있었다. 첫째, 정확도기반 크 레아티닌검사 신빙도조사사업 원시자료에 크레아티닌검사의 바이어스에 영향을 미치는 주된 요인인 calibrator 정보가 충 분하지 않아 세부적인 분석에 제한점이 있었다. 둘째, 정확도 기반 크레아티닌검사 신빙도조사사업에 참여하는 기관 숫자 가 일반화학프로그램에 비교하여 많지 않았고, 무엇보다 소규 모 검사실의 참여가 적어 신빙도조사사업 결과를 국내 임상검 사실의 크레아티닌검사 정확도 현황으로 일반화하는데 제한 점이 있었다. 셋째, 각 참여기관에서 사용하는 검사장비와 검 사시약 종류가 다양하여 세부 그룹으로 나누어 분석하는데 제 한점이 있었다.

결론적으로, 대한임상검사정도관리협회에서 주관한 정확도 기반 크레아티닌검사 외부정도관리에 참여한 기관의 평균적 인 크레아티닌검사 바이어스는 회차가 거듭될수록 점차 감소 하는 경향을 보여 외부정도관리에 참여하는 기관의 평균적인 크레아티닌검사 정확도가 점차 개선되고 있다고 판단할 수 있 다. 다만, 2017년에도 여전히 2\%-3\%가량의 positive 바이어 스가 있으므로 지속적으로 정확도기반 신빙도조사사업에 참 여하여 크레아티닌검사의 정확도 향상을 위해 노력해야 할 것 으로 생각된다.

\section{감사의 글}

이 연구는 대한임상검사정도관리협회의 2018년도 학술연구
과제 연구비(과제 번호: 2018-05) 지원으로 수행되었다.

\section{SUPPLEMENTARY MATERIALS}

Supplementary materials can be found via https://doi. org/10.15263/jlmqa.2019.41.1.13.

\section{REFERENCES}

1. Zegers I, Schimmel H. To harmonize and standardize: making measurement results comparable. Clin Chem 2014;60:911-3.

2. Greg Miller W, Myers GL, Lou Gantzer M, Kahn SE, Schonbrunner ER, Thienpont LM, et al. Roadmap for harmonization of clinical laboratory measurement procedures. Clin Chem 2011;57:1108-17.

3. Chung S, Jun SH, Song WH, Song J. Six years' experience of accuracy-based proficiency testing for HbAlc in Korea. J Lab Med Qual Assur 2015;37:92-100.

4. Inker LA, Schmid CH, Tighiouart H, Eckfeldt JH, Feldman HI, Greene T, et al. Estimating glomerular filtration rate from serum creatinine and cystatin C. N Engl J Med 2012;367:20-9.

5. Kidney Disease: Improving Global Outcomes (KDIGO) CKD Work Group. KDIGO 2012 clinical practice guideline for the evaluation and management of chronic kidney disease. Kidney Int Suppl 2013;3:1-150.

6. Kidney Disease: Improving Global Outcomes (KDIGO) Acute Kidney Injury Work Group. KDIGO clinical practice guideline for acute kidney injury. Kidney Int Suppl 2012;2:1-138.

7. Myers GL, Miller WG, Coresh J, Fleming J, Greenberg N, Greene $\mathrm{T}$, et al. Recommendations for improving serum creatinine measurement: a report from the Laboratory Working Group of the National Kidney Disease Education Program. Clin Chem 2006;52:5-18.

8. Killeen AA, Ashwood ER, Ventura CB, Styer P. Recent trends in performance and current state of creatinine assays. Arch Pathol Lab Med 2013;137:496-502.

9. Levey AS, Coresh J, Greene T, Marsh J, Stevens LA, Kusek JW, et al. Expressing the Modification of Diet in Renal Disease Study equation for estimating glomerular filtra- 


\section{Journal of LABORATORY MEDICINE and QUALITY ASSURANCE}

Tae-Dong Jeong et al $\bullet$ Accuracy-Based PT for Creatinine

tion rate with standardized serum creatinine values. Clin Chem 2007;53:766-72.

10. Stevens LA, Manzi J, Levey AS, Chen J, Deysher AE, Greene T, et al. Impact of creatinine calibration on performance of GFR estimating equations in a pooled indi- vidual patient database. Am J Kidney Dis 2007;50:21-35.

11. Miller WG. The role of proficiency testing in achieving standardization and harmonization between laboratories. Clin Biochem 2009;42:232-5. 